\title{
УДК: 634.8.07(477) \\ https://doi.org/10.53040/gppb7.2021.86 \\ ОЦЕНКА ПРОСТОРАНСТВЕННОЙ И ВРЕМЕННОЙ ИЗМЕНЧИВОСТИ ПОКАЗАТЕЛЕЙ ПРОДУКТИВНОСТИ ВИНОГРАДА В ЦЕНТРАЛЬНЫХ И ЮЖНЫХ РАЙОНАХ ОДЕССКОЙ ОБЛАСТИ
}

\author{
Ляменко Галина, Мельник Элла, Суздалова Вера, Бузовская Марина, \\ Булаева Юлия, Попова Анна \\ Национальный научный центр «Институт виноградарства и виноделия \\ имени B.E. Таирова»,Таиров, Украина, е-таil: lgv53@ukr.net
}

Результаты анализа агроклиматических условий (условий морозоопасности и теплообеспеченности) в центральных районах виноградарской зоны Украины в разрезе зимнего и вегетационного периодов свидетельствуют о значительной межгодовой изменчивости и тенденции уменьшения степени их неблагоприятности в последние 20 , и особенно 10 лет. Результаты исследований состояния виноградных насаждений позволили провести количественный анализ связи показателей продуктивности винограда (урожая, содержания сахара в сусле, титруемой кислоты и ГАК) с показателями агроклиматических условий.

Разрабатывалась математическая модель формирования продуктивности сортов винограда в виде сплайн-функции. Выполнено обоснование основных факторов экологических ресурсов и продуктивности винограда, проведено исследование их пространственно-временной изменчивости. Формировались отдельно совокупности показателей ампелоэкологических ресурсов в пространственном и временном разрезе. С применением методов математической статистики и теории вероятности оценивалась точность и достоверность ампелоэкологической информации, определялись основные статистические характеристики рядов совокупности каждого из показателей и проверялась гипотеза об их однородности и изотропности.

Реализация модели выполнена для территории базовых хозяйств ГП ОХ «Таировское» и ГП ОХ им. А.В. Суворова (Одесская область). Оценивалась временная изменчивость показателей производительности столовых и технических сортов винограда разного срока созревания. При анализе пространственной изменчивости выявлено, что наименьшее содержание сахара в соке ягод отмечено на участках, расположенных вблизи водоемов, где амплитуды температур более сглажены. В районах более отдаленных от побережья, уровень содержания сахара выше на 1-2 единицы.

Более тесная связь содержания сахара в сусле винограда отмечается с суммами дневных температур и с разницей сумм дневных и ночных температур, коэффициенты корреляции составляют соответственно 0,54 и 0,42. Для сорта Каберне Совиньон коэффициенты корреляции содержания сахара с суммами дневных температур, разницей сумм дневных и ночных температур и суммой среднесуточных температур составляют $0,73,0,44$ и 0,20 соответственно. Для сортов ранних сроков созревания множественные коэффициенты корреляции содержания сахара с суммой дневных температур за июнь-сентябрь, количеством дней со среднесуточной температурой воздуха выше $20^{\circ} \mathrm{C}$, датами перехода среднесуточной температуры воздуха через $10^{\circ} \mathrm{C}$ весной составляли $0,81 \pm 0,06$, a для сортов позднего срока созревания - с гидротермическим коэффициентом за июнь-сентябрь, датами перехода среднесуточной температуры воздуха через $15^{\circ} \mathrm{C}-0.90 \pm 0,03$. 